Original Article

\title{
ANTI-INFLAMMATORY, ANALGESIC AND ANTIOXIDANT ACTIVITIES OF HYDRO-ACETONIC EXTRACT FROM WISSADULA AMPLISSIMA VAR. ROSTRATA (SHUM. AND THONN.) R. E. FRIES
}

\author{
EMMANUEL A. M. THIOMBIANO1, NOUFOU OUEDRAOG02,3, MARTIN KIENDREBEOG01*, ${ }^{*}$ MARIUS LOMPO² $^{2}$
}

${ }^{1}$ Laboratoire de Biochimie et Chimie Appliquées (LABIOCA), Université Ouaga I Pr Joseph KI-ZERBO, 03 BP 7021 Ouagadougou 03, Burkina Faso, ${ }^{2}$ Departement Medecine et Pharmacopée Traditionnelles-Institut de Recherche en Sciences de la Santé, Centre Nationale de Recherche Scientifique et Technologique (MEPHATRA-IRSS/CNRST), 03 BP 7192 Ouagadougou 03, Burkina Faso, ${ }^{3}$ Laboratoire de Pharmacologie et de Toxicologie, Université Ouaga I Pr Joseph KI-ZERBO, 03 BP 7021 Ouagadougou 03, Burkina Faso

Email: martinkiendrebeogo@yahoo.co.uk

Received: 18 Feb 2017 Revised and Accepted: 27 Jun 2018

\begin{abstract}
Objective: The present study aims to investigate anti-inflammatory, analgesic and antioxidant effects of the hydroacetonic extract (HAE) from Wissadula amplissima whole plant and to determine its polyphenol and flavonoid contents.

Methods: Extraction was achieved by soaking defatted W. amplissima with aqueous acetone solvent. Acute toxicity and pharmacological investigations were performed per os and intraperitoneally on Naval Medical Research Institute (NMRI) mice. The carrageenan-induced paw edema and the acetic acid-induced writhing tests were used to assess the in vivo anti-inflammatory and analgesic activities. Inhibition of xanthine oxidase and lipoxygenase were carried out in vitro using endpoint spectrophotometric assays at $295 \mathrm{~nm}$ and $234 \mathrm{~nm}$. 2,2-diphenyl-1-picrylhydrazyl (DPPH), Ferric Reducing Antioxidant Power (FRAP), lipid peroxidation and desoxyribose degradation assays were used to point out antioxidant activities of extract. Aluminium chloride colorimetric method was used to determine total flavonoids content when and total phenolic content was measured by the method Folin-ciocalteu reagent.
\end{abstract}

Results: $W$. amplissima's HAE exhibited a slight acute toxicity with no lethality observed. Significant $(\mathrm{p}<0.05)$ anti-inflammatory and analgesic activities were recorded as well as strong inhibitory activities on lipoxygenase and xanthine oxidase. W. amplissima's HAE also demonstrated interesting antioxidant activities particularly in preventing lipid peroxidation. Polyphenol and flavonoid contents were respectively estimated to $64.33 \pm 1.34 \mathrm{mg}$ Gallic Acid Equivalent (GAE) and 35.17 $\pm 0.77 \mathrm{mg}$ Quercetin Equivalent (QE) per $100 \mathrm{mg}$ of W. amplissima's HAE.

Conclusion: HAE of W. amplissima exhibited a promising anti-inflammatory and analgesic potential compared to the reference (acetylsalicylic acid, Hydrocortisone, paracetamol) and regarding the inhibition of lipoxygenase and lipid peroxidation. The anti-inflammatory and analgesic activities seem to be related to the antioxidant and enzymes inhibitors compounds of the plant extract.

Keywords: Anti-inflammatory, Antioxidant, Lipoxygenase, Xanthine oxidase, Wissadula amplissima

(C) 2018 The Authors. Published by Innovare Academic Sciences Pvt Ltd. This is an open access article under the CC BY license (http://creativecommons.org/licenses/by/4.0/) DOI: http://dx.doi.org/10.22159/ijpps.2018v10i8.13416

\section{INTRODUCTION}

Populations of all the continents use plants for their various needs in terms of shelter, clothing, food, flavours and fragrances as not the least, medicines [1]. The last decade has witnessed a growing number of populations who rely on traditional remedies derived from medicinal plant and tremendous progress in medicinal plant research. This worldwide trend towards the use of natural plant remedies has created an enormous need for information about the properties and uses of the medicinal plant for the treatment of minor ailments to more complex diseases.

Malvaceae botanical family consists of dicotyledonous plants with at least 2300 species in 200 genera [2]. Wissadula amplissima a member of this family is present throughout Africa from Cape Verde to Senegal and Eritrea to South Africa [3]. In the central region of Burkina Faso, species belonging to this family are well known and used by traditional practitioners to treat several diseases. Ethnopharmacological studies report the use of this species in folk medicine to treat vomiting, severe diarrheas, mucosa, skin and bronchus inflammation; inflammatory diseases, fever and allergies. The roots of the plant are used to treat anemia, hemorrhages and as a fortifying [4].

Inflammation is a complex defensive system of the body against any aggression. It involves in pathogenesis of diseases including infections, cancer, diabetes, atherosclerosis, arthritis. Several mediators such as cytokines (TNF $\alpha$, IL6, IL 1 1 ), free radical (reactive oxygen species (ROS), prostaglandins (PGE2) and leukotriene are released during inflammation response. Lipoxygenase (LOX) involved leukotriene synthesis play an important role in inflammation maintenance [5].
Previous biological investigations have demonstrated that methanol extract of Wissadula amplissima leaves possess antioxidant properties (2, 2-diphenyl-1-pricrylhydrazyl method) and anti-inflammatory capacity using carrageenan-induced paw edema in chicks [6].

In the best of our knowledge, there is no scientific information concerning the in vitro anti-inflammatory activities using the enzymatic method, in vivo anti-inflammatory activities using carrageenan-induced paw edema in mice, the toxicity and analgesic activities of this species.

The aim of this present study was to investigate anti-inflammatory (in vivo and in vitro), analgesic and antioxidant effects of the hydroacetonic extract (HAE) from Wissadula amplissima whole plant and to determine polyphenol and flavonoids contents.

\section{MATERIALS AND METHODS}

\section{Plant materials}

The whole plant of Wissadula amplissima var. Rostrata (Shum. and Thonn.) R. E. Fries (Malvaceae) was harvested in January 2013 at Gampela $(25 \mathrm{~km}$, East of Ouagadougou, Burkina Faso). Botanical identity was assessed by Professor Jeanne Millogo-Rasolodimby from laboratoire de biologie et ecologie vegetale (University of Ouagadougou, Burkina Faso) where a voucher specimen (CI: 16884) was deposited. Plant material was dried at room temperature, pulverized and stored in an airtight bag until use.

\section{Animals and housing}

Naval medical research institute (NMRI) mice ( 7 to $8 \mathrm{w}$ old, 25 to $35 \mathrm{~g}$ body weight), provided by the animal housing facility of the 
University of Ouagadougou, were used. Mice were kept in an environmentally controlled breeding room $\left(20-25^{\circ} \mathrm{C}, 75 \%\right.$ humidity, $12 \mathrm{~h}$ photoperiod), fed with standard laboratory food and water ad libitum. Mice were fasted $17 \mathrm{~h}$ before experiments. Investigation at animals was conducted in accordance with the official journal of european committee in 1991 and approved by the institutional committee regarding the care and use of animals for the experimental procedure in 2010; CEE509 [7, 8].

\section{Chemicals}

Chemicals were from analytical grade. Acetic acid, acetylsalicylic acid, allopurinol, carrageenan, dimethylsulfoxide, 2,2-diphenyl-1picrylhydrazyl, hydrocortisone, lecithin, 15-lipoxygenase (EC 1.13.11.12), paracetamol, quercetin, sodium chloride, xanthine and xanthine oxidase (EC 1.1.3.22) were purchased from Sigma-Aldrich (St. Louis, MO, USA). Ascorbic acid, desoxyribose, ferric trichloride, hydrochloric acid, potassium hexacyanoferrate, thiobarbituric acid and trichloroacetic acid were supplied by Labosi (Paris, France). Boric acid, ethylenediamine tetraacetic acid, gallic acid, linoleic acid, sodium carbonate, sodium phosphate dibasic, sodium phosphate monobasic, sodium tetraborate, trichloroacetic acid and all solvent used were sourced from Prolabo (Paris, France).

\section{Extract preparation}

Powdered plant material (50 g) was defatted with petroleum ether $(500 \mathrm{ml})$ in a soxhlet extractor and then soaked $\left(48 \mathrm{~h}, 25{ }^{\circ} \mathrm{C}\right.$, continuous stirring) in acetone/water (80/20, $500 \mathrm{ml})$. Extract was filtrated, concentrated in a vacuum evaporator (Büchi Rotavapor R200) and lyophilized (Telstar Cryodos 50) to get $44.7 \mathrm{~g}$ of hydro acetone extract (HAE). HAE was stored at $4{ }^{\circ} \mathrm{C}$ until use.

\section{Acute toxicity test}

Acute toxicity was carried out to determinate lethal dose ( $L D_{50}$ ). NMRI mice orally received 500,1000, 2000,3000,5000 mg/kg and intraperitoneally 1000 and $1500 \mathrm{mg} / \mathrm{Kg}$ of body weight (bw). After the administration of extract, the animals were observed for 2 to 72 $\mathrm{h}$. Then morbidity or mortality and changes in behavior have been noted [9].

\section{Anti-edematous activity}

Anti-edematous activity was evaluated according to Winter et al. [10]. Seven groups of six mice were randomly used. HAE of Wissadula amplissima was administrated per os at 2 different doses (200 and $300 \mathrm{mg} / \mathrm{kg} \mathrm{bw}$ ) and intraperitoneally at $150 \mathrm{mg} / \mathrm{kg}$ bw to sample groups. Control groups received only vehicle (Water per os, $0.9 \% \mathrm{NaCl}$ ip) while reference groups received reference compounds (acetylsalicylic acid at $150 \mathrm{mg} / \mathrm{kg}$ bw per os, hydrocortisone at $10 \mathrm{mg} / \mathrm{kg}$ bw ip). One hour later, $50 \mu \mathrm{l}$ of carrageenan $(1 \%$ in $0.9 \% \mathrm{NaCl})$ was injected under the aponeurosis plantar of the hind paw at each mouse. Paw edema volume was measured at time intervals of $1 \mathrm{~h}, 3 \mathrm{~h}$ and $5 \mathrm{~h}$ after carrageenan injection using plethysmometer (model Ugo Basil, n ${ }^{\circ} 7141$, Italy). The anti-edematous activity was evaluated in the percentage of reduction of the edema in treated mice compared to negative control using the following formula:

$$
\% \text { Inhibition }=\frac{\mathrm{A}-\mathrm{B}}{\mathrm{A}} \times 100
$$

A represents the average difference paw edema volume in the negative control group and $B$ represents the average difference of paw edema volume in treated groups of mice.

\section{Analgesic activity}

The analgesic activity was evaluated according to the acetic acidinduced writhing test as described by Sawadogo et al. [11] with minor modifications. Six groups of 6 randomly selected mice were used. HAE of Wissadula amplissima was administrated per os at 2 different doses (200 and $300 \mathrm{mg} / \mathrm{kg}$, bw) and intraperitoneally at $150 \mathrm{mg} / \mathrm{Kg}$ by to sample groups. Control groups received only vehicle (Water per os, $0.9 \% \mathrm{NaCl}$ ip) while reference group received paracetamol (100 mg/kg bw per os). One hour after drug administration, mice received $0.6 \%$ of acetic acid injection $(10 \mathrm{ml} / \mathrm{kg}$ bw). A number of writhing was recorded within 5 to 20 min after acetic acid injection. The analgesic effect was evaluated according to the following formula:

$$
=\frac{\begin{array}{l}
\text { Inhibition } \\
\text { Number of Writhes } \\
(\text { Control })
\end{array}-\text { Number of Writhes }_{(\text {Sample })}}{\text { Number of Writhes }_{(\text {Control })}} \times 100
$$

\section{Lipoxygenase (LOX) inhibitory activity}

The inhibition of lipoxygenase was assayed according to the spectrophotometric method described by Lycklander and Malterud [12] with slight modifications. Briefly, $100 \mu \mathrm{l}$ of enzyme solution $(200 \mathrm{U} / \mathrm{ml})$ prepared in boric acid buffer $(0.2 \mathrm{M}$; $\mathrm{pH} 9.0)$ was mixed with $25 \mu \mathrm{l}$ of HAE of Wissadula amplissima ( $1 \mathrm{mg} / \mathrm{ml}$ in DMSO) and then incubated at room temperature for $3 \mathrm{~min}$. Reaction was then initiated by the addition of $125 \mu \mathrm{l}$ of the substrate $(250 \mu \mathrm{M}$ of linoleic acid) and the velocity was recorded for $3 \mathrm{~min}$ at $234 \mathrm{~nm}$ with a microplate reader (Epoch, BioTeck instruments, USA). DMSO was used as a control while quercetin and ibuprofen were used as reference compounds. Percentage of lipoxygenase inhibition was calculated according to the equation:

$$
\% \text { Inhibition of lipoxygenase }=\frac{\mathrm{V} 0_{\text {Control }}-\mathrm{V} 0_{\text {Sample }}}{\mathrm{V} 0_{\text {Control }}} \times 100
$$

V0 Control: Enzymatic activity without inhibitor, V0 $0_{\text {Sample }}$ Enzymatic activity in presence of HAE or reference compounds.

\section{Xanthine oxidase (XO) inhibitory activity}

Xanthine oxidase inhibition was assessed according to the spectrophotometric method reported by Filha et al. [13] with slight modifications. In brief, $20 \mu \mathrm{l}$ of enzyme solution $(0.28 \mathrm{U} / \mathrm{ml}$ in phosphate buffer $\mathrm{pH} 7.5$ ) was mixed with $20 \mu \mathrm{l}$ of HAE of Wissadula amplissima (1 mg/ml in DMSO), $60 \mu$ of phosphate buffer (pH 7.5) and then incubated at room temperature for $2 \mathrm{~min}$. The reaction was initiated by the addition of $100 \mu \mathrm{l}$ of the substrate $(150 \mu \mathrm{M}$ of xanthine in phosphate buffer) and the velocity was recorded for 3 min at $295 \mathrm{~nm}$ with a microplate reader (Epoch, BioTeck instruments, USA). DMSO was used as a control while allopurinol was used as reference inhibitor. Percentage of xanthine inhibition was calculated according to the equation:

$$
\% \text { Inhibition of xanthine oxidase }=\frac{\mathrm{V} 0_{\text {Control }}-\mathrm{V} 0_{\text {Sample }}}{\mathrm{V} 0_{\text {Control }}} \times 100
$$

V0 Control: Enzymatic activity without inhibitor, V0 $0_{\text {Sample: Enzymatic }}$ activity in presence of HAE or allopurinol.

\section{DPPH radial scavenging assay}

DPPH radical scavenging activity was evaluated as described by Kadam et al. [14]. Briefly, $200 \mu \mathrm{l}$ of freshly prepared DPPH solution $(0.02 \mathrm{mg} / \mathrm{ml}$ in methanol) was mixed with $100 \mu \mathrm{l}$ of HAE of Wissadula amplissima (from 100 to $25 \mu \mathrm{g} / \mathrm{ml}$ in methanol). After shaking, the mixture was incubated for $15 \mathrm{~min}$ in darkness at room temperature and absorbance measured at $517 \mathrm{~nm}$ against a blank (methanol) with a microplate reader (Epoch, BioTeck instruments, USA). Inhibition of DPPH radical was calculated as following:

$$
\% \text { Inhibition of DPPH radical }=\frac{\mathrm{Abs}_{\text {Blank }}-\mathrm{Abs}_{\text {Sample }}}{\mathrm{Abs}_{\text {Blank }}} \times 100
$$

Abs Blank and Abssample are the absorbances of the blank and sample reactions. IC 50 (Concentration scavenging $50 \%$ of DPPH radicals) was graphically determined. Gallic acid and Quercetin were used as positive controls.

\section{Ferric reducing antioxidant power (FRAP) assay}

FRAP assay was performed according to Lamien-Meda et al. [15]. HAE of Wissadula amplissima $(100 \mu \mathrm{l}, 1 \mathrm{mg} / \mathrm{ml}$ in methanol) was mixed with $250 \mu \mathrm{l}$ of phosphate buffer $(0.2 \mathrm{M}, \mathrm{pH} 6.6)$ and $250 \mu \mathrm{l}$ of potassium hexacyanoferrate solution (1\% in water). After $30 \mathrm{~min}$ of incubation $\left(50^{\circ} \mathrm{C}\right), 250 \mu \mathrm{l}$ of trichloroacetic acid (10\% in water) was added and the mixture was centrifuged (2000 $\mathrm{g}$ for $10 \mathrm{~min}$ ). The supernatant $(125 \mu \mathrm{l})$ was mixed with water $(125 \mu \mathrm{l})$ and $25 \mu \mathrm{l}$ of fresh $\mathrm{FeCl}_{3}$ solution ( $0.1 \%$ in water) and then absorbance was read at $700 \mathrm{~nm}$ with a microplate reader (Epoch, BioTeck instruments, 
USA). Ascorbic acid was used to plot a calibration curve $\left(\mathrm{R}^{2}=0.99\right)$. Reducing power was expressed as $\mathrm{mg}$ ascorbic acid equivalent per gram of HEA (mg AAE/g). Gallic acid and quercetin were used as positive controls.

\section{Lipid peroxidation inhibition assay}

Inhibition of lipid peroxidation was determined following the method described by Kulkarni et al. [16]. Briefly, $100 \mu \mathrm{l}$ of HAE of Wissadula amplissima (from 100 to $25 \mu \mathrm{g} / \mathrm{ml}$ in methanol) were added to $100 \mu \mathrm{l}$ of lecithin $(10 \mathrm{mg} / \mathrm{ml}$ in phosphate buffer $10 \mathrm{mmol}$, $\mathrm{pH}$ 7.4), $\mathrm{FeCl}_{3}(100 \mu \mathrm{l} ; 40 \mathrm{mmol})$ and ascorbic acid (100 $\mu \mathrm{l} ; 20$ mmol) for 1 hour incubation at $37{ }^{\circ} \mathrm{C}$. $\mathrm{HCl}(1 \mathrm{ml}, 0.25 \mathrm{~N})$ supplemented with $15 \%$ TCA and $0.375 \%$ TBA was added to the mixture, incubated for $15 \mathrm{~min}$ at $100{ }^{\circ} \mathrm{C}$ and centrifuged $(3000 \mathrm{rpm}$ for $10 \mathrm{~min}$ ). The absorbance of the supernatant was read at $532 \mathrm{~nm}$ against a blank (methanol) with a microplate reader (Epoch, BioTeck instruments, USA). Inhibition of lipid peroxidation was calculated as following:

$$
\% \text { Inhibition of lipid peroxidation }=\frac{\mathrm{Abs}_{\text {Blank }}-\mathrm{Abs}_{\text {Sample }}}{\mathrm{Abs}_{\text {Blank }}} \times 100
$$

Abs $_{\text {Blank }}$ and Abssample are the absorbances of the blank and sample reactions. IC 50 (Concentration inhibiting $50 \%$ of lipid peroxidation) was graphically determined. Quercetin was used as a positive control.

\section{Desoxyribose degradation assay}

The ability of HAE of Wissadula amplissima to prevent the degradation of the desoxyribose was determined using the method described by Houghton et al. [17]. Briefly, freshly prepared 2desoxyribose $(100 \mu \mathrm{l}, 28 \mathrm{mmol}$ in phosphate buffer $50 \mathrm{mmol}, \mathrm{pH}$ 7.4), EDTA (500 $\mu \mathrm{l} ; 1.04 \mathrm{mmol}), \mathrm{FeCl}_{3}(100 \mu \mathrm{l} ; 100 \mathrm{mmol}), \mathrm{H}_{2} \mathrm{O}_{2}$ $(100 \mu \mathrm{l}, 1.0 \mathrm{mmol})$ and ascorbic acid $(100 \mu \mathrm{l}, 1.0 \mathrm{mmol})$ was mixed and incubated at $37{ }^{\circ} \mathrm{C}$ for 1 hour with $\operatorname{HAE}(100, \mu \mathrm{l} ; 1 \mathrm{mg} / \mathrm{ml})$. Thiobarbituric acid (1 $\mathrm{ml}$ of $1 \%$ aqueous solution) and trichloroacetic acid (1 $\mathrm{ml}$ of $2.8 \%$ aqueous solution) was added to the mixture and incubated at $100{ }^{\circ} \mathrm{C}$ for $20 \mathrm{~min}$. The resultant mixture was centrifuged ( $3000 \mathrm{~g}$ for $10 \mathrm{~min}$ ). Absorbance of the organic layer containing thiobarbituric acid reactive substances was measured at $532 \mathrm{~nm}$ against a blank (methanol) with a microplate reader (Epoch, BioTeck instruments, USA). Inhibition of Desoxyribose degradation was calculated as following:

$\%$ Inhibition of desoxyribose degradation

$$
=\frac{\mathrm{Abs}_{\text {Blank }}-\mathrm{Abs}_{\text {Sample }}}{\mathrm{Abs}_{\text {Blank }}} \times 100
$$

$\mathrm{IC}_{50}$ (Concentration inhibiting $50 \%$ of desoxyribose degradation) was graphically determined. Quercetin was used as a positive control.

\section{Polyphenol and flavonoids content}

Total polyphenol content was determined according to Singleton et al. [18]. HAE of $W$. Amplissima (25 $\mu \mathrm{l}, 100 \mu \mathrm{g} / \mathrm{ml}$ in Methanol) was mixed with Folin Ciocalteu Reagent $(105 \mu \mathrm{l}, 0.2 \mathrm{~N})$ and $5 \mathrm{~min}$ later with sodium bicarbonate $(100 \mu \mathrm{l}, 75 \mathrm{~g} / \mathrm{l})$. After 1-hour incubation, absorbance was measured at $760 \mathrm{~nm}$ against a blank with a microplate reader (BioTeck instruments, USA). A standard calibration curve $\left(\mathrm{Y}=0.005 \mathrm{X}+0.00968 ; \mathrm{R}^{2}=0.99\right)$ was plotted using Gallic acid (0-100 mg/l). Polyphenol content was expressed as mg of Gallic acid equivalent to $100 \mathrm{mg}$ of extract (mg GAE/100 $\mathrm{mg}$.

The total flavonoids content was estimated according to ArvouetGrant et al. [19]. HAE of W. amplissima (75 $\mu \mathrm{l}, 100 \mu \mathrm{g} / \mathrm{in}$ methanol) was mixed with aluminium trichloride (75 $\mu \mathrm{l}, 2 \%$ in methanol). Absorbance was subsequently read at $415 \mathrm{~nm}$ after $10 \mathrm{~min}$ incubation against a blank with a microplate reader (Epoch, BioTeck instruments, USA). A standard calibration curve $(\mathrm{y}=$ $\left.0.02891 \mathrm{X}+0.0036 ; \mathrm{R}^{2}=0.99\right)$ was plotted using Quercetin $(0-100$ $\mathrm{mg} / \mathrm{l}$ ). Flavonoid content was expressed as $\mathrm{mg}$ of Quercetin equivalent to $100 \mathrm{mg}$ of extract (mg QE/100 mg).

\section{Statistical analysis}

Experiments were carried out in triplicate and results expressed as mean \pm SEM. ANOVA analysis $(\mathrm{p}<0.05)$ and linear regression were performed with GraphPad Prism 5 and XLSTAT 7.1 software.

\section{RESULTS}

\section{Acute toxicity}

Any mortality was observed at the highest doses of $W$. amplissima HAE (5000 mg/Kg bw per os, $1500 \mathrm{mg} / \mathrm{Kg}$ bw intraperitoneally) on mice model. However behavioral signs (prostration, loss of exploration instinct, sleepiness and feed refusal) were observed within two hours following the extract administration per os at 5 $000 \mathrm{mg} / \mathrm{kg}$ bw. Although behavioral signs disappear after $2 \mathrm{~d}$ and mice regain their initial vitality. These results point out that HAE did not exhibit any acute toxicity effect on NMRI mice at the doses tested.

\section{Anti-inflammatory activity in vivo}

The anti-inflammatory activity of $W$. amplissima HEA was assessed in vivo through its anti-edematous and analgesic effects as summarized in table 1 and table 2 .

Either in oral or intraperitoneal (i. p.) administration, edema induced by carrageenan injection was significantly $(\mathrm{p}<0.05)$ reduced in a time-dependent manner within $5 \mathrm{~h}$ after inflammation, that is not the case of acetylsalicylic acid administrated per os. In our experimental conditions, HEA administrated per os at 200 and 300 $\mathrm{mg} / \mathrm{kg}$ bw were less active than acetylsalicylic acid $(150 \mathrm{mg} / \mathrm{kg}$ bw per os) within an hour but were more efficient at the fifth hour. HEA $(150 \mathrm{mg} / \mathrm{kg}$; i. p.) exhibited the same effect than hydrocortisone (15 $\mathrm{mg} / \mathrm{kg}$ ) within $3 \mathrm{~h}$, the latter being more effective at the fifth hour. Regarding the analgesic activity, reduction of contortions dosedependent when HAE is administrated per os. Either in oral (200 and $300 \mathrm{mg} / \mathrm{kg} \mathrm{bw})$ or intraperitoneal $(150 \mathrm{mg} / \mathrm{kg} \mathrm{bw})$ administration HAE was more effective than paracetamol (100 mg/kg, bw, per os).

\section{Inhibition of lipoxygenase and xanthine oxidase}

Table 3 show that HAE possess significant inhibitory activities on both enzymes respectively with $72.80 \%$ inhibition for xanthine oxidase (XO) and $68.99 \%$ inhibition for lipoxygenase (LOX) when tested at $100 \mu \mathrm{g} / \mathrm{ml}$ (final concentration). Regarding LOX inhibition, HAE is more potent than quercetin $(52.97 \%)$ but less active than ibuprofen $(78.61 \%)$. Concerning XO inhibition, HEA is slightly weaker than quercetin (93.63\%) and allopurinol (95.49\%).

\begin{tabular}{|c|c|c|c|c|c|c|c|}
\hline \multirow{2}{*}{\multicolumn{2}{|c|}{ Samples administration (mg/kg) }} & \multicolumn{3}{|c|}{ Volume of edema (ml) } & \multicolumn{3}{|c|}{ Inhibition percentage (\%) } \\
\hline & & $1 \mathrm{~h}$ & $3 \mathbf{h}$ & $5 \mathrm{~h}$ & $1 \mathrm{~h}$ & $3 \mathbf{h}$ & $5 \mathrm{~h}$ \\
\hline \multirow[t]{4}{*}{ peros } & Control (Nacl 0.9\%) & $0.21 \pm 0.04$ & $0.33 \pm 0.01$ & $0.36 \pm 0,01$ & --- & --- & --- \\
\hline & HAE (200) & $0.16 \pm 0.01$ & $0.19 \pm 0.01^{*}$ & $0.12 \pm 0.01 *$ & $21.66 \pm 3.67$ & $38.36 \pm 1.22$ & $65.69 \pm 2.69$ \\
\hline & HAE (300) & $0.13 \pm 0.03^{*}$ & $0.23 \pm 0.03^{*}$ & $0.07 \pm 0.04^{*}$ & $38.09 \pm 1.52$ & $48.83 \pm 5.68$ & $76.06 \pm 4.39$ \\
\hline & acetylsalicylic acid (150) & $0.10 \pm 0.01^{*}$ & $0.16 \pm 0.01^{*}$ & $0.15 \pm 0.01^{*}$ & $48.47 \pm 6.81$ & $50.96 \pm 2.37$ & $56.47 \pm 4.80$ \\
\hline \multirow[t]{3}{*}{ i. $p$. } & Control (Nacl 0.9\%) & $0.22 \pm 0.05$ & $0.36 \pm 0.03$ & $0.38 \pm 0,02$ & --- & --- & --- \\
\hline & HAE (150) & $0.15 \pm 0.03$ & $0.22 \pm 0.05^{*}$ & $0.20 \pm 0.07^{*}$ & $24.85 \pm 1.45$ & $35.75 \pm 1.6$ & $41.11 \pm 2.00$ \\
\hline & Hydrocortisone (15) & $0.15 \pm 0.05^{*}$ & $0.21 \pm 0.01^{*}$ & $0.16 \pm 0.02 *$ & $24.28 \pm 2.50$ & $35.95 \pm 5.90$ & $53.51 \pm 2.80$ \\
\hline
\end{tabular}

Table 1: Effect of HAE of $W$. amplissima on edema induced in mice by the injection of carrageenan

Data are expressed as mean values \pm SEM $(n=6)$, HAE: Hydro acetone extract of $W$. amplissima, *Values within the same sub-column harbouring asterisk mark in superscript are significantly different from the control group $(\mathrm{p}<0.05)$. 
Table 2: Effect of HAE of W. amplissima against writhing induced by acetic acid

\begin{tabular}{llll}
\hline \multicolumn{2}{c}{ Samples administration (mg/kg) } & Number of Writings & Inhibition percentage (\%) \\
\hline per os & Control & $66.27 \pm 6.50$ & -- \\
& HAE (200) & $28.66 \pm 14.75^{*}$ & $56.74 \pm 2.41$ \\
& HAE (300) & $24.66 \pm 4.84^{*}$ & $62.78 \pm 6.67$ \\
\multirow{2}{*}{$p$} & Paracetamol (100) & $35.16 \pm 2.13^{*}$ & $46.94 \pm 2.78$ \\
& Control & $74.40 \pm 3.79$ & -- \\
\end{tabular}

Data are expressed as mean values \pm SEM $(n=6)$, HAE: Hydro acetone extract of W. amplissima *Values within the same sub-column harboring asterisk mark in superscript are significantly different from the control group $(\mathrm{p}<0.05)$

Table 3: Inhibition of xanthine oxidase and lipoxygenase by HAE from W. amplissima

\begin{tabular}{lll}
\hline Samples $(\mu \mathbf{g} / \mathbf{m l})$ & Xanthine oxidase inhibition (\%) & Lipoxygenase inhibition (\%) \\
\hline HAE (100) & $72.80 \pm 1.44^{\mathrm{b}}$ & $68.99 \pm 1.39^{\mathrm{b}}$ \\
Allopurinol (100) & $95.49 \pm 0.47^{\mathrm{a}}$ & nd \\
Quercetin (100) & $93.63 \pm 0.36^{\mathrm{a}}$ & $52.97 \pm 0.71^{\mathrm{c}}$ \\
Ibuprofen (100) & nd & $78.61 \pm 0.12^{\mathrm{a}}$ \\
\hline
\end{tabular}

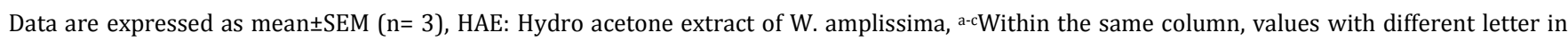
superscript are significantly different $(\mathrm{p}<0.05)$.

\section{Antioxidant activity, polyphenol and flavonoid content}

The antioxidant potential of the HAE of $W$. amplissima to scavenge DPPH radical, to prevent ferric reduction, lipid peroxidation and desoxyribosse degradation has been compared with those of Quercetin. As shown (table 4), HAE of W. amplissima demonstrates an interesting antioxidant potential. Indeed, in the lipid peroxidation model, HAE of $W$. amplissima exhibited the same antioxidant activity than quercetin, our antioxidant reference. Although HAE of $W$. amplissima was less active than quercetin in the other antioxidant model tested, it ferric reducing power was only 1.5 lower than that of quercetin and $\mathrm{IC}_{50}$ values recorded in DPPH and desoxyribose assays were lower than $100 \mu \mathrm{g} / \mathrm{ml}$. Total polyphenol and flavonoid content of HAE from $W$. amplissima were respectively $64.33 \pm 1.34 \mathrm{GAE} / 100 \mathrm{mg}$ of extract and $35.17 \pm 0.77$ $\mathrm{QE} / 100 \mathrm{mg}$ of extract.

Table 4: Antioxidant activity, polyphenol and flavonoid content of HAE from W. amplissima

\begin{tabular}{|c|c|c|}
\hline & \multicolumn{2}{|l|}{ Samples } \\
\hline & HAE & Quercetin \\
\hline DPPH assay $\left(\mathrm{IC}_{50}, \mu \mathrm{g} / \mathrm{ml}\right)$ & $57.33 \pm 2.3^{\mathrm{b}}$ & $1.35 \pm 0.13^{\mathrm{a}}$ \\
\hline Desoxyribose assay $\left(\mathrm{IC}_{50}, \mu \mathrm{g} / \mathrm{ml}\right)$ & $32 \pm 2.51^{b}$ & $10.06 \pm 0.11^{\mathrm{a}}$ \\
\hline Lipid peroxidation assay $\left(\mathrm{IC}_{50}, \mu \mathrm{g} / \mathrm{ml}\right)$ & $11.9 \pm 0.1^{\mathrm{a}}$ & $9.13 \pm 0.11^{\mathrm{a}}$ \\
\hline FRAP assay $(\mu \mathrm{mol}$ AAE/g) & $120.37 \pm 2.52^{\mathrm{b}}$ & $187.77 \pm 2.27^{\mathrm{a}}$ \\
\hline Polyphenol content (mg GAE/100 mg) & $64.33 \pm 1.34$ & - \\
\hline Flavonoid content (mg GAE/100 mg) & $35.17 \pm 0.77$ & - \\
\hline
\end{tabular}

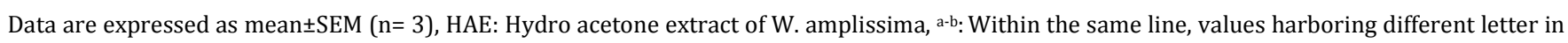
superscript are significantly different $(\mathrm{p}<0.05)$.

\section{DISCUSSION}

The present study demonstrated that hydro acetonic extract (HAE) of $W$. amplissima possess potential pharmacological properties including antioxidant, anti-edematous, analgesic and inhibiting enzymes (xanthine oxidase and lipoxygenase) effects. HAE of whole $W$. amplissima was considered as slightly toxic conferring to toxicity scale established by Hodge and Sterner [9], because the $\mathrm{LD}_{50}$ was above $5000 \mathrm{mg} / \mathrm{kg}$ of body weight.

Edema induced by the carrageenan injection is an animal model assay commonly used to evaluate the anti-inflammatory activity of substances. Carrageenan injection provokes the release of several chemical mediators which are the basis of the inflammatory process. The inflammatory response is biphasic $[20,21]$ : the first phase lasted one hour that mediated by histamine, serotonin and bradykinin; the second phase (above one hour) is due to the biosynthesis of prostaglandins [22]. HAE of W. amplissima whole plant inhibited the edema in a dose-dependent manner and in all these phases. Thus, the extract may have an antagonistic action against histamine, bradykinin, serotonin and the prostaglandins biosynthesis. The highest value of inhibition was obtained at the fifth hour. This suggests that the inhibitor action of the HAE of $W$. amplissima could be acted more on the cyclooxygenases which are implicated in the synthesis of prostaglandins.

The extract was effective as well as it was orally administrated or by intraperitoneal injection. The molecular structure plays a key role in the choice of the way used to administrate a drug. In this study results shown that whatever the administration mode was (orally or intraperitoneally) the HAE of $W$. amplissima was effective. This suggests that bioactive compounds, responsible for the anti-inflammatory properties found in this herbal mixture have been easily absorbed through the intraperitoneal way or via the gastrointestinal mucosa.

Writhing induced by acetic acid injection is a method used to study the peripheral analgesic effect of a substance [23]. Abdominal contortions induced by acetic acid injection were used to evaluate the analgesic effect of HAE of $W$. amplissima. Test showed that the extract had a nonopioid analgesic potential either oral or intraperitoneal administration. The pain caused by the injection of acetic acid is due to the release of serotonin, bradikynin, substance $\mathrm{P}$ and prostaglandins $\left(\mathrm{PGE}_{2 \alpha}\right.$ et $\left.\mathrm{PGF}_{2 \alpha}\right)$. These chemical mediators stimulate peripheral nociceptive neurons and induce the vascular permeability [24]. HAE of $W$. amplissima inhibited abdominal contraction in a dose-dependent manner. Analgesic effect of HAE of $W$. amplissima could be related to the inhibition of these chemical mediators.

Lipoxygenases (LOXs) play an important role in the biosynthesis of leukotrienes which are pro-inflammatory mediators involved in the physiopathology of inflammatory diseases. Leukotriene LTB4 is a powerful pro-inflammatory chemotactic agent for a variety of leukocytes; and leukotrienes (C4, D4, E4) are responsible of vascular permeability and smooth muscle contraction [25]. HAE of $W$. amplissima inhibited lipoxygenase; it suggests that extract prevents leukotrienes actions inhibiting LOX. 
The enzyme xanthine oxidase (XO) catalyzes the oxidation of hypoxanthine and xanthine to uric acid in the purine catabolic pathway [26]. Uric acid plays a crucial role in pathogenesis hyperuricemia, cardiovascular diseases [27]. HAE of W. amplissima whole plant inhibited XO. HAE of $W$. amplissima whole plant was evaluated for its in vitro anti-inflammatory activity by inhibition of LOX and XO enzymes. The inhibition of these enzymes is a potential therapeutic to treat asthma, hyperuricemia and gout.

During inflammatory process, excessive production of free radical such as reactive oxygen species (ROS) are released causing cells lysis, pro-inflammatory cytokines (TNF $\alpha$, IL1 $\beta$, IL6) production and LOX and cyclooxygenases expression [28]. The inhibitor effect of HAE of $W$. amplissima whole plant against ROS, was evaluated using $\mathrm{DPPH}$, desoxyribose degradation assay, FRAP and lipid peroxidation methods that were widely used to determine the antioxidant capacity of substances. The extract exhibited antioxidant activity with four methods, however, its effect was smaller than quercetin. In this study different methods were used because it takes more than one antioxidant method to assess the mode of action of antioxidants [29]. The antioxidant capacity of $W$. amplissima HAE contributes to reinforce its anti-inflammatory effect.

The results of this study reveal that HAE of $W$. amplissima contains polyphenol and flavonoid compounds which could be responsible of evidenced pharmacological activities.

\section{CONCLUSION}

The present study showed that the hydroacetonic extract of Wissadula amplissima possesses antioxidant, analgesic and antiinflammatory (in vitro and in vivo) effects. Data obtained represent a scientific basis for the traditional use of Wissadula amplissima to manage inflammatory diseases. Further bio-guided investigations would help in the isolation of compounds and in the clear elucidation of their mechanism of action.

\section{ACKNOWLEDGEMENT}

Authors are grateful to APPEAR 75, TWAS 12-044 RG/BIO/AF/AC_G (granted to Dr M KIENDREBEOGO) and IFS F/5374-1 (Granted to Dr N. OUEDRAOGO) projects for providing laboratory facilities that have made this work possible.

\section{AUTHORS CONTRIBUTIONS}

All the author have contributed equally

\section{CONFLICT OF INTERESTS}

Authors have no conflict of interest to declare

\section{REFERENCES}

1. Gurib-Fakim A. Medicinal plants: traditions of yesterday and drugs of tomorrow. Mol Aspects Med 2006;27:1-93.

2. Vadivel V, Sriram S, Brindha P. Distribution of flavonoids among Malvaceae family members a review. Int J Green Pharm 2016;10(1 Suppl):33-45.

3. Oyen LPA. Wissadula rostrata (Schumach and thonn.) planchon ex Hook. In: Brink M, Achigan-Dako EG. editors. Plant resources of tropical Africa 16 Fibres. Wageningen, PROTA's Foundation; 2012. p. 659.

4. Nacoulma OG. Plantes médicinales et pratiques médicales traditionnelles au Burkina Faso: cas du plateau central. Tomes I et II. Thèse de Doctorat d'Etat ès Sciences Naturelles. Université de Ouagadougou; 1996.

5. Ouédraogo N, Sawadogo RW, Tibiri A, Bayet C, Lompo M, Hay $\mathrm{AE}$, et al. Pharmacological properties and related constituents of stem bark of Pterocarpus erinaceus poir. (Fabaceae). Asian Pac J Trop Med 2012;5:46-51.

6. Mensah AY, Donkor PO, Fleischer TC. Anti-inflammatory and antioxidant activities of leaves of Wissadula amplissima var. rostrata. Afr J Tradit Complement Altern Med 2011;8:185-95.

7. Ghosh MN. Fundamentals of experimental pharmacology. 2nd Ed. Scientific Book Agency, Calcutta; 1984.
8. Journal Officiel des communautés européennes. The directive, 86/609/CEE; 1986.

9. Hodge HC, Sterner JH. Determination of substances acute toxicity by LD50. Am Ind Hyg Assoc J 1943;10:93-9.

10. Winter CA, Risley EA, Nuss GW. Carrageenan-induced edema in hind paw of rats as assay of anti-inflammatory drug. Proc Soc Exp Biol Med 1962;111:544-7.

11. Sawadogo WR, Boly R, Lompo M, Somé N, Lamien CE, Guissou IP, et al. Anti-inflammatory, analgesic and antipyretic activities of Dicliptera verticillata. Int J Pharmacol 2006;2:435-8.

12. Lycklander IM, Malterud KE. Lypophilic flavonoids from Orthosiphon spicatus as inhibitors of 15-lipoxygenase. Acta Pharm Nord 1992;4:159-66.

13. Ferraz-Filha ZS, Vitolo IF, Fietto LG, Lombardi JA, Sau-deGuimaraes DA. Xanthine oxidase inhibitory activity of Lychnophora species from Brazil ("Arnica"). J Ethnopharmacol 2006;107:79-82.

14. Kadam VJ, Joshi YM, Sawant HP, Jadhav TA. The free radical scavaging activity of an aqueous solution of black salt. Int J Pharm Sci 2010;2(2 Suppl):95-6.

15. Lamien Meda A, Lamien CE, Compaore MMY, Meda RTN, Kiendrebeogo M, Zeba B, et al. Polyphenol content and antioxidant activity of fourteen wild edible fruits from Burkina Faso. Molecules 2008;13:581-94.

16. Kulkarni AP, Aradhya M, Divakar S. Isolation and identification of a radical scavenging antioxidant-punicalagin from pith and carpellary membrane of pomegranate fruit. Food Chem 2004;87:551-7.

17. Houghton PJ, Zarka R, De las Heras B, Hoult JRS. Fixed oil of Nigella sativa and derived thymoquinone inhibit eicosanoid generation in leucocytes and lipid peroxidation. Planta Med 1995;61:33-6.

18. Singleton VL, Rossi JA. Colorimetry of total phenolics with phosphomolybdic-phosphotungstic acid reagents. Am J Enol Vitic 1965;16:144-58.

19. Arvouet Grand AB, Vennat AP, Legret P. Standardization of propolis extract and identification of key components. J Pharm Belg 1994;49:462-29.

20. Vinegar R, Schreiber W, Hugo R. Biphasic development of carrageenan edema in rats. J Pharmacol Exp Ther 1969;166:96103.

21. Reanmongkol W, Noppapan T, Subhadhirasakul S. Antinociceptive, antipyretic, and anti-inflammatory activities of Putranjiva roxburghii Wall. leaf extract in experimental animals. J Nat Med 2009;63:290-6.

22. Kumar NR, Kumar NS, Gangadhar PB. Anti-inflammatory activity of Traumeel (a homeopathic preparation) in experimental animals-rats. Asian J Pharm Clin Res 2015;8:317-9.

23. Kamurthy H, Samulatha Ch, Rao NS, Sudhakar M. Antinociceptive activity of stigmosterol-3-glyceryl-2-linoleiate, campesterol and daucosterol isolated from Aerva lanata Linn. aerial parts. Asian J Pharm Clin Res 2013;6:149-52.

24. Shah BN, Patel NP, Pandya P. Role of leukotriene in inflammation and anti-leukotriene therapy. J Pharm Res 2008;1:113-23.

25. Werz Oliver. 5-lipoxygenase: cellular biology and molecular pharmacology. Curr Drug Targets Inflamm Allergy 2002;1:23-44.

26. Okamoto $\mathrm{K}$, Kusano $\mathrm{T}$, Nishino $\mathrm{T}$. Chemical nature and reaction mechanisms of the molybdenum cofactor of xanthine oxidoreductase. Curr Pharm Des 2013;19:2606-14.

27. Hershfield MS. Gout and uric acid metabolism. In: Goldman L, Bennett JC. editors. Cecil Textbook of Medicine. 21st ed. London: Saunders Company; 2000. p. 1541-8.

28. Mirshafiey A, Mohsenzadegan M. The role of reactive oxygen species in the immunopathogenesis of rheumatoid arthritis. Iran J Allergy Asthma Immunol 2008;7:195-202.

29. Dudonne S, Xavier V, Philippe C, Marion W, Jean-Michel M. Comparative study of antioxidant properties and total phenolic content of 30 plant extracts of industrial interest using DPPH, ABTS, FRAP, SOD, and ORAC assays. J Agric Food Chem 2009;57:1768-74. 